\title{
Spatio-Temporal Variations of Indoor Bioaerosols in Different Socio-Economic Zones of an Urban Metropolis
}

\author{
Palak Balyan ${ }^{1 *}$, Chirashree Ghosh ${ }^{1}$, Shukla Das ${ }^{2}$, B.D. Banerjee ${ }^{3}$ \\ ${ }^{1}$ Environmental Pollution Laboratory, Department of Environmental Studies, University of Delhi, Delhi, India \\ ${ }^{2}$ Department of Microbiology, University College of Medical Sciences and GTB Hospital, \\ University of Delhi, Delhi, India \\ ${ }^{3}$ Department of Biochemistry, University College of Medical Sciences and GTB Hospital, \\ University of Delhi, Delhi, India
}

Received: 25 July 2017

Accepted: 17 December 2017

\begin{abstract}
Bioaerosols are significant constituents of the indoor environment and may be associated with numerous adverse health effects. This study presents the results of monitoring of aerosolised bacterial and fungal count by passive settle plate method at different socio-economic residential zones (SEZ) of Delhi, an urban metropolis. The counts of aerosolised bacteria and fungi were estimated across five seasons of a tropical climate. We observed that the different SEZs showed different degrees of microbial counts in the indoor air. The highest microbial exposure was noted in the low SEZ. The microbial count showed a similar seasonal pattern across different SEZs. The lowest microbial count was observed during the pre-monsoon season and the highest during post-monsoon and winter seasons. A mixed effect model showed a significant effect of socio-economic zone and season on both indoor bacterial and fungal counts. Although temperature and relative humidity were significantly associated with indoor microbial count, they could not fully explain variations of indoor microbial counts in the mixed model.
\end{abstract}

Keywords: bioaerosol, indoor aerosolised bacteria, indoor aerosolised fungi, seasonal variation, socio-economic zone

\section{Introduction}

Bioaerosols are ubiquitous in the environment. Biogenic aerosol particles are a significant part of atmospheric aerosols, varying from quarter to half of the total number of aerosol particles [1]. The air serves

*e-mail: balyan.palak@gmail.com primarily as a temporary habitat and dispersal medium for microorganisms [2, 3]. Air contaminated with microbes can be a source of infection for human beings. Bioaerosols can induce the occurrence of pulmonary symptoms, headache, allergies, sick building syndrome, and toxic reactions, as well induce deep infections of internal organs such as kidneys, endocardium, bone marrow and intestines [4, 5]. Humans spend around $90 \%$ of their time in enclosed microenvironments; homes in particular account for a large proportion of 
time spent, especially by women, children, and old people $[6,7]$. Thus, it is desirable to minimize indoor bioaerosol exposure; two important steps in this are proper estimation and clear understanding of the factors affecting its occurrence.

Indoor bioaerosols are either generated in an indoor environment or drawn from the outdoor environment. Housing factors like human occupancy and activities - like talking, sneezing, coughing, walking, washing, use of toilets, vacuuming, making the bed, sleeping, and folding clothes, housing type, the type of construction material, flooring, housing space, ventilation pattern, temperature, humidity, concentration of gases, lighting or dust concentration and the presence of moulds and dampness because of defective plumbing and air conditioning - have been reported to affect the count and types of microbes inside a house, by their generation, aerosolisation and re-suspension [8-21].

Outdoor bioaerosols enter the indoor environment through a range of avenues such as heating, ventilation and air conditioning systems, doors, windows, cracks in the walls, adhering to objects or human bodies, and drinking water systems [8, 22, 23]. The microbial community of outdoor air varies with the location, land use pattern, presence of open sewage and solid waste management $[4,24]$. The adequacy and type of ventilation system determines the rate of seasonal air exchange and therefore also the rate of ingression and dispersion of bioaerosols between indoor and outdoor environments $[25,26]$.

The indoor and outdoor sources or factors that affect bioaerosol counts vary with season and socioeconomic status [27, 28]. Socio-economic status is also one of prime determiners of residential mobility and segregation [29, 30]. Residential mobility and segregation occur due to differential land and house prices in different areas of a metropolis and succession of socio-economic status across generations. It leads to the development of socio-economic zoning of residential areas in a metropolis [31-34]. Such zones can be called socio-economic zones (SEZs) having agglomeration of common housing parameters and life style based on socio-economic status. Hence, such socio-economic zones may have a bearing on bioaerosol exposure of its inhabitants.

It is necessary to monitor exposure to aerosolised microbes across residential houses in different socioeconomic zones (SEZs) and seasons. The aim of the present study was to estimate the count of aerosolised bacteria and fungi in the indoor residential environment of houses belonging to different socio-economic zones of Delhi, a metropolis, across five seasons of tropical climate.

\section{Methodology}

Aerosolised bacterial and fungal counts were measured in three residential areas of different socio- economic status (low, mid, and high SEZs) within the north campus of the University of Delhi. The measurements were taken weekly across all seasons for two years (November 2013 to October 2015). Delhi has five seasons in a cycle: winter, spring, pre-monsoon, monsoon, and post-monsoon [35].

\section{Selection of Sampling Sites}

Sampling sites were selected based on the Delhi government's residential property circle rates such that one colony was selected from high-, mid- and low-circle rate zones [36]. Three colonies were selected near to the north campus of the University of Delhi in order to minimize the effect of meteorological variability on bioaerosol counts. The socio-economic status of residents of three selected colonies were confirmed by a pre-sampling assessment of socio-economic status by applying Kuppuswamy's scale of socio-economic status for urban areas in India that divide socio-economic status (SES) into low, mid and high SESs through a pilot study of randomly selected 50 homes from each zone [37].

\section{Study Sites}

Low socio-economic zone (low SEZ): a slum in the vicinity of the university campus was selected. The slum had narrow lanes with open sanitary drains filled with household solid waste and wastewater. There were multiple waste dumping sites within the colony. Each house was enclosed on three sides by other houses and the houses had inadequate natural ventilation. Most of the houses were in a dilapidated condition without a separate toilet and bathroom. The population density across the low SEZ was $23 / 100 \mathrm{~m}^{2 *}$.

Mid socio-economic zone (mid SEZ): the residential quarters of clerical staff of the University of Delhi were selected. This area had a large open space and a closed sewage system. Household solid waste was dumped in an area outside the residential area. The houses had two stories and were open on two sides (back and front). Each house had adequate natural ventilation and separate toilet and bathroom. The housing space was larger than that in the low SEZ and the human occupancy rate was much lower $\left(6 / 100 \mathrm{~m}^{2}\right)$.

High socio-economic zone (high SEZ): a plush area near the University of Delhi with privately owned buildings was selected. This area had wide roads with an adequate sewage system. Solid refuse was dumped at a designated site outside the area. There was a closed sewage system for liquid waste. The majority of the houses were big, with air conditioning systems, and were open on two sides. Most, if not all, of the houses belonged to residents of high socio-economic status. Each house had its own toilet and bathroom. The area had a lower human occupancy rate $\left(3 / 100 \mathrm{~m}^{2}\right)$ 
than the mid SEZ. All houses were well constructed and had good-quality flooring. ${ }^{1}$

\section{Culture Media}

The present study monitored the culturable fraction of bioaerosols viz. aerosolised bacteria and fungi. For detection and enumeration of fungi and bacteria, petri plates with enriched media were used. The fungal fraction was sampled over potato dextrose agar (PDA) media, which promotes the growth of fungi; it has a low $\mathrm{pH}$ and contains antibiotics, thereby inhibiting the growth of bacteria [38]. Aerosolised bacteria were sampled on blood agar, which allows for both isolation and the cultivation of a wide variety of fastidious microbes [1, 39].

\section{Bioaerosol Sampling}

Each socio-economic zone was divided into three grids with a rough sketch of sites created by presampling on site visits. Air sampling was conducted in the living room of three houses, one house from each grid selected by using a random number table, in each of the three SEZs. Aerosolised microbial counts were measured using the sedimentation-based passive settle plate method [40]. To minimize the effect of diurnal variations on the bioaerosol counts, sampling was conducted between noon and 14:00 [41]. A set of two agar plates (one each for bacteria and fungi) were kept $1 \mathrm{~m}$ above the ground and $1 \mathrm{~m}$ away from the walls, exposed for one hour for estimating microbial counts.

The residents were allowed to continue with their normal activities during sampling. The outdoor bioaerosol sampling was also done simultaneously. On site, both indoor and outdoor relative humidity $(\mathrm{RH})$ and temperature were recorded during the sampling period using a handheld weather monitor (Kestrel A33, USA) with a logging interval of $1 \mathrm{~min}$. The inoculated blood agar plates were incubated at $36^{\circ} \mathrm{C}$ for 48 hours for fast-growing bacteria, whereas the PDA plates were kept at $28^{\circ} \mathrm{C}$ for 72 hours for fungus to develop into a visible colony. Bacterial and fungal colonies, which grew on a particular plate, were counted, and the result was noted as the number of cells or cell aggregates capable of developing in the form of colonies (CFU - colony forming units). The resultant colonies were reported as CFU/plate.

\section{Statistical Analysis}

A mixed-effects model (based on covariance parameter) of the statistical computer program SPSS (IBM, Version 23) was used to determine the statistical significance of variations of indoor aerosolised bacterial and fungal counts across SEZs and seasonal variation. Paired t-test was conducted to compare the indoor and outdoor count of aerosolised bacteria and fungi across seasons in three SEZs. Pearson correlation coefficients were calculated to analyse the association between meteorological variables and indoor bacterial and fungal counts. Separate all-variable mixed models were generated for both indoor bacterial and fungal counts. Since the objective of the study was to compare the counts of microbes in the indoor air of different SEZs and across different seasons, both SEZ and season were entered as fixed effects. Season-site interaction was included as a random effect to adjust for possible different effects of the season on other factors at different SEZs. Temperature and $\mathrm{RH}$ were added as fixed effects in the all variable mixed model to test whether the effect of season on the indoor bioaerosols counts was mediated exclusively by temperature or RH. Similarly, the effect of outdoor microbial counts on indoor microbial counts was tested by adding count of outdoor microbes as a fixed effect.

\section{Results}

The indoor bacterial and fungal count measured over two five-season-cycles (November 2013- October 2015) in three SEZs are presented in Table 1. The number of the microorganisms in the indoor residential air of three SEZs varied depending on SEZ and season of sampling.

\section{Variation in Indoor Bioaerosol Counts across Socio-Economic Zones}

The highest mean bacterial and fungal counts were found in the indoor air of the low SEZ. The fungal counts were comparable in the mid and high SEZs. However, during pre-monsoon season, the indoor fungal count was highest in the high SEZ. Variation across economic zones was significant for both indoor bacterial and fungal counts $(p<0.01)$ when entered alone in a covariance-based mixed model (Table 1).

\section{Seasonal Variation in Indoor Bioaerosol Counts}

Throughout the seasonal cycle, bacterial count well exceeded fungal count indoors. Both bacterial and fungal counts, indoor as well as outdoor, followed a similar seasonal pattern (Fig. 1): lowest in premonsoon season, and increasing from pre-monsoon to post-monsoon season, when the highest counts were recorded. Overall, bioaerosol counts varied throughout the season cycle in all three SEZs. Seasonal variation, when entered alone in a covariance-based mixed model, was significant for both bacterial and fungal counts.

* Size calculated from data of a health survey conducted by researchers at the study sites. 
Table1. Seasonal variations in indoor bacterial and fungal counts (CFU/plate) in three socio-economic zones.

\begin{tabular}{|c|c|c|c|c|c|c|c|c|}
\hline & $\begin{array}{c}\text { Winter } \\
(\mathrm{n}=22)\end{array}$ & $\begin{array}{c}\text { Spring } \\
\mathrm{n}=16)\end{array}$ & $\begin{array}{c}\text { Pre monsoon } \\
(\mathrm{n}=22)\end{array}$ & $\begin{array}{c}\text { Monsoon } \\
(\mathrm{n}=22)\end{array}$ & $\begin{array}{c}\text { Post monsoon } \\
(\mathrm{n}=22)\end{array}$ & $\begin{array}{c}p \text {-value } \\
\text { Season }\end{array}$ & $\begin{array}{c}p \text {-value } \\
\text { SEZ }\end{array}$ \\
\hline \multicolumn{7}{|c|}{ Indoor bacterial count } \\
\hline Low SEZ & $310.07 \pm 37.11 *$ & $222.31 \pm 24.18$ & $127.23 \pm 28.19$ & $190.11 \pm 57.60$ & $377.23 \pm 46.92$ & $<0.01$ & $<0.01$ \\
\hline Mid SEZ & $267.64 \pm 41.45$ & $173.43 \pm 21.22$ & $120.09 \pm 26.05$ & $161.32 \pm 44.91$ & $311.46 \pm 58.61$ & $<0.01$ & $<0.01$ \\
\hline High SEZ & $253.14 \pm 36.24$ & $162.49 \pm 21.33$ & $125.11 \pm 30.68$ & $184.62 \pm 60.34$ & $322.94 \pm 64.35$ & $<$ \\
\hline \multicolumn{7}{|c|}{ Indoor fungal count } & $<0.01$ \\
\hline Low SEZ & $144.49 \pm 13.59$ & $149.64 \pm 22.48$ & $53.60 \pm 14.71$ & $128.88 \pm 43.35$ & $199.47 \pm 49.66$ & $<0.01$ & $<0.01$ \\
\hline Mid SEZ & $119.15 \pm 21.60$ & $116.95 \pm 20.11$ & $49.36 \pm 9.94$ & $109.49 \pm 34.72$ & $156.09 \pm 39.09$ & $<$ \\
\hline High SEZ & $114.46 \pm 16.95$ & $123.28 \pm 24.28$ & $69.71 \pm 13.09$ & $105.60 \pm 25.11$ & $136.32 \pm 17.23$ & $<0.01$ & $<$ \\
\hline
\end{tabular}

*Mean value \pm standard error

\section{Relationship between Indoor and Outdoor Microbial Concentrations}

Although bacterial count followed a similar seasonal trend in both indoor and outdoor environments (Fig. 1), the aerosolised bacterial count was higher in the indoor environment across all seasons and all socioeconomic zones, except the post-monsoon season in the high SEZ (Table 2). The difference between indoor and outdoor aerosolised bacterial counts was significant during monsoon season for all SEZs and during the winter season in the low and mid SEZs; it was also significant at a $90 \%$ confidence level during the winter in the high SEZ. For fungi, the mean outdoor counts were higher than the indoor counts in all cases except during monsoon season in the mid and high SEZs. The difference between indoor and outdoor fungal concentration was significant during winter, spring, and pre-monsoon season in all SEZs, as well as during postmonsoon season in the low SEZ $(p<0.05)$.

\section{Effect of Temperature and Relative Humidity on Indoor Bacterial and Fungal Counts}

The outdoor and indoor temperature and relative humidity had a significant effect $(p<0.01)$ on indoor bacterial and fungal count when tested alone in the statistical model. A matrix correlating temperature and relative humidity with indoor bacterial and fungal counts is given in Table 3. The outdoor and indoor

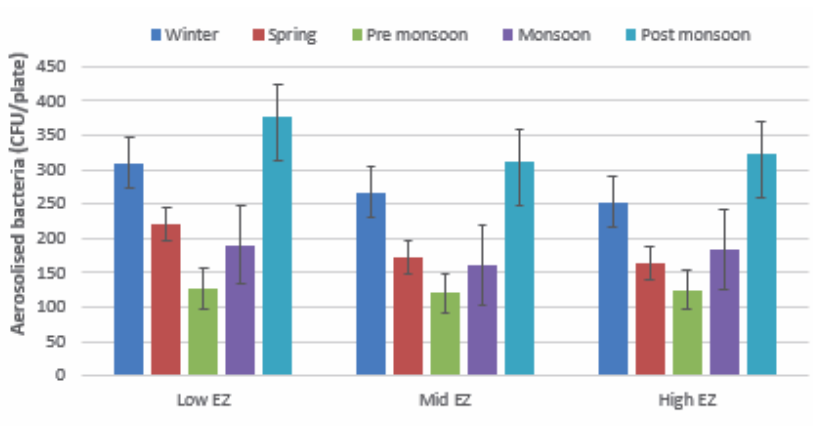

1a) Indoor Bacteria

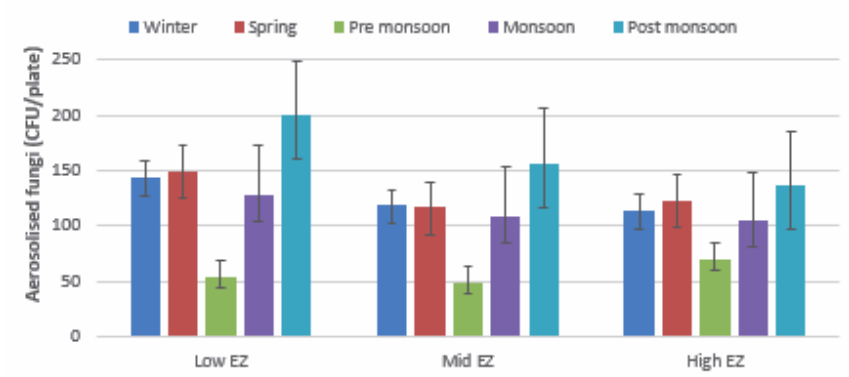

2a) Indoor fungi

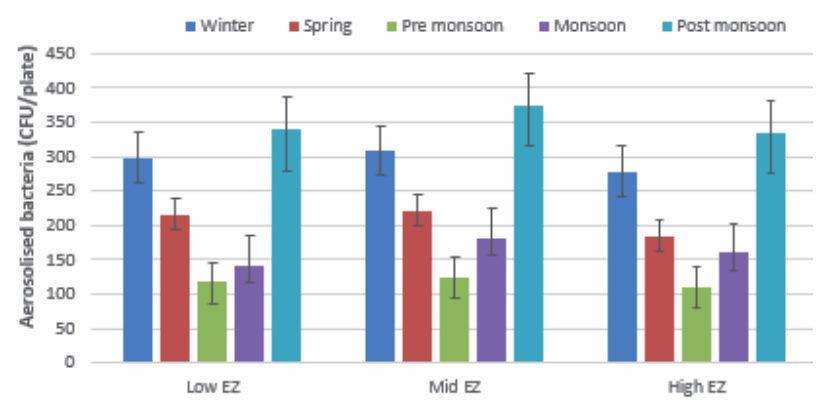

1b) Outdoor Bacteria

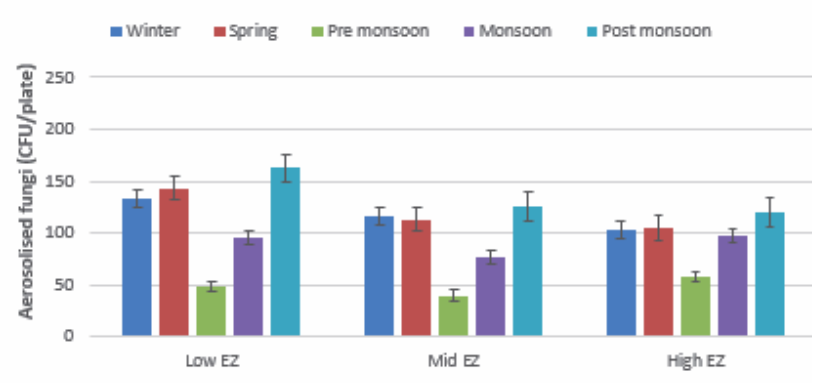

2b) Outdoor fungi

Fig. 1. Seasonal trend of indoor (1a and $2 \mathrm{a})$ and outdoor ( $1 \mathrm{~b}$ and $2 \mathrm{~b})$ microbial concentrations across three socio-economic zones. 
Table 2. Comparison of indoor and outdoor counts of airborne microbes, analyzed by paired t-tests.

\begin{tabular}{|c|c|c|c|c|c|c|}
\hline \multirow{2}{*}{ Indoor bacterial count } & \multicolumn{2}{|c|}{ Low SEZ } & \multicolumn{2}{|c|}{ Mid SEZ } & \multicolumn{2}{|c|}{ High SEZ } \\
\hline & Mean difference* & $p$-value & Mean difference & $p$-value & Mean difference & $p$-value \\
\hline Winter & 35.29 & 0.05 & 36.80 & $<0.01$ & 6.03 & 0.09 \\
\hline Spring & 7.99 & 0.32 & 3.68 & 0.48 & 2.54 & 0.71 \\
\hline Pre monsoon & 6.24 & 0.24 & 9.73 & 0.17 & 13.76 & $<0.01$ \\
\hline Monsoon & 41.82 & $<0.01$ & 35.62 & $<0.01$ & 14.04 & 0.02 \\
\hline Post monsoon & 7.66 & 0.43 & 4.41 & 0.67 & -4.90 & 0.29 \\
\hline \multicolumn{7}{|c|}{ Indoor fungal count } \\
\hline Winter & -17.36 & 0.01 & -21.80 & $<0.01$ & -8.93 & $<0.01$ \\
\hline Spring & -5.18 & 0.03 & -29.05 & 0.02 & -11.52 & 0.01 \\
\hline Pre monsoon & -12.63 & $<0.01$ & -9.06 & $<0.01$ & -7.44 & 0.04 \\
\hline Monsoon & -11.54 & 0.16 & 3.20 & 0.56 & 0.892 & 0.76 \\
\hline Post monsoon & -9.45 & 0.04 & -5.80 & 0.35 & -5.28 & 0.12 \\
\hline
\end{tabular}

Mean difference* $=$ indoor bioaerosol count - outdoor bioaerosol count

temperature correlated negatively with both bacterial and fungal count, whereas both outdoor and indoor humidity correlated positively with bacterial and fungal counts.

\section{Combined Effect of all Variables on Indoor Bioaerosols Counts}

A model incorporating all variables was built to predict their effects on both indoor bacteria and fungi by entering SEZ, season, respective outdoor aerosolised microbial count, outdoor and indoor temperature, and relative humidity into the mixed model (Tables 4 and 5). The variable that could retain significant effects were outdoor fungal count $(p<0.01)$ and indoor relative humidity $(p<0.05)$ on indoor fungal count (Table 4$)$, and SEZ $(p<0.01)$, season $(p=0.02)$ and outdoor bacterial concentration $(p<0.01)$ on indoor bacterial count (Table 5).

The pairwise comparison of indoor bacterial concentration in different SEZs is presented in Table 6 . The indoor bacteria count was significantly higher in the low $(p<0.01)$ and mid $(p<0.05)$ SEZs compared to the high SEZ.

\section{Discussion}

\section{Variation in Indoor Bioaerosol Counts across Socio-Economic Zones}

The mean indoor bacterial and fungal counts were higher in the low SEZ than in the mid and high SEZs, though this difference was statistically significant only

Table 3. Correlation matrix showing Pearson coefficients of temperature and relative humidity with indoor microbial counts.

\begin{tabular}{|c|c|c|c|c|c|c|}
\hline \multirow{2}{*}{ Indoor bacterial count } & \multicolumn{2}{|c|}{ Low SEZ } & \multicolumn{2}{|c|}{ Mid SEZ } & \multicolumn{2}{|c|}{ High SEZ } \\
\hline & r-value & $p$-value & r-value & $p$-value & r-value & $p$-value \\
\hline Outdoor temperature & -0.54 & $<0.01$ & -0.50 & $<0.01$ & -0.42 & $<0.01$ \\
\hline Indoor temperature & -0.49 & $<0.01$ & -0.39 & $<0.01$ & -0.23 & 0.02 \\
\hline Outdoor relative humidity & 0.52 & $<0.01$ & 0.49 & $<0.01$ & 0.38 & $<0.01$ \\
\hline Indoor relative humidity & 0.39 & $<0.01$ & 0.31 & 0.001 & 0.34 & 0.001 \\
\hline \multicolumn{7}{|c|}{ Indoor fungal count } \\
\hline Outdoor temperature & -0.47 & $<0.01$ & -0.62 & $<0.01$ & -0.53 & $<0.01$ \\
\hline Indoor temperature & -0.42 & $<0.01$ & -0.34 & 0.001 & -0.12 & 0.23 \\
\hline Outdoor relative humidity & 0.59 & $<0.01$ & 0.68 & $<0.01$ & 0.56 & $<0.01$ \\
\hline Indoor relative humidity & 0.54 & $<0.01$ & 0.41 & $<0.01$ & 0.62 & $<0.01$ \\
\hline
\end{tabular}


in the case of bacteria (Tables 1, 4-6). The waste and stagnant water from uncovered sanitary drains having sewage sludge, narrow alleys, multiple dumping heaps, and high human occupancy in small residential dwellings across the low SEZ provide a favourable environment for the generation and growth of microbes. Similar to the present study, a study conducted by Nasir et al. [8] in Pakistan also noted a higher microbial concentration at a study site, which had characteristics similar to the low SEZ in the present study. Studies conducted by Boruta et al. [4] and Michałkiewicz et al. [42] reported sewage sludge and dumping heap of solid waste as a good source of bioaerosols. Sewage sludge and heaped dumping pile provide suitable conditions for growth or survival to the microorganisms, prolonging their survival time in the environment. Also, a study conducted by Yassin et al. [43] observed a rise in counts of indoor bioaerosols with a fall in the level of environmental and indoor hygiene and housing standards across residences in Kuwait. Furthermore, a study conducted by Fang et al. [44] in China reported a rise in indoor microbial counts in residential environments with an increase in human occupancy.

Two large-scale cross-sectional surveys conducted by the Central Pollution Control Board (CPCB) of India $[45,46]$ observed a high prevalence of respiratory morbidity in people residing in a low socio-economic zone in the area of current study. It suggests that high bioaerosol exposure could be one of the causal factors for the high prevalence of respiratory morbidity observed in the low socio-economic zone $[45,46]$.

However, during pre-monsoon season, the indoor fungal counts were observed in the high SEZ, which had temperature and relative humidity maintained by

Table 4. Effects of season, economic status, temperature, relative humidity and outdoor fungal count on indoor fungal count.

\begin{tabular}{|c|c|c|c|c|}
\hline Parameter & Estimate & $p$-value & \multicolumn{2}{|c|}{ 95\% Confidence Interval } \\
\hline & & & Lower Bound & Upper Bound \\
\hline Season & & 0.25 & & \\
\hline Socio-economic zone & & 0.19 & & \\
\hline Outdoor temperature & -0.52 & 0.33 & -1.56 & 0.52 \\
\hline Indoor temperature & -1.15 & 0.06 & -2.36 & 0.05 \\
\hline Outdoor relative humidity & 0.42 & 0.29 & -0.36 & 1.20 \\
\hline Indoor relative humidity & 0.36 & 0.04 & 0.05 & 2.36 \\
\hline Outdoor fungal count & 0.85 & $<0.01$ & 0.73 & 0.97 \\
\hline
\end{tabular}

Table 5. Effect of season, economic status, temperature, relative humidity and outdoor bacterial count on indoor bacterial count.

\begin{tabular}{|c|c|c|c|c|}
\hline Parameter & Estimate & $p$-value & \multicolumn{2}{|c|}{ 95\% Confidence Interval } \\
\hline & & & Lower Bound & Upper Bound \\
\hline Season & & 0.02 & & \\
\hline Socio-economic zone & & 0.01 & & \\
\hline Outdoor temperature & 0.31 & 0.67 & -1.141 & 1.769 \\
\hline Indoor temperature & -1.54 & 0.06 & -3.182 & 0.076 \\
\hline Outdoor relative humidity & -0.75 & 0.20 & -1.888 & 0.395 \\
\hline Indoor relative humidity & 1.21 & 0.06 & -0.078 & 2.346 \\
\hline Outdoor fungal count & 0.82 & $<0.01$ & 0.729 & 0.916 \\
\hline
\end{tabular}

Table 6. Site-wise comparison of indoor bacterial counts.

\begin{tabular}{|c|c|c|c|c|c|}
\hline \multirow{2}{*}{ SEZ A } & \multirow{2}{*}{ SEZ B } & $\begin{array}{c}\text { Mean Difference } \\
(\mathrm{A}-\mathrm{B})\end{array}$ & \multirow{2}{*}{$p$-value } & \multicolumn{2}{|c|}{$95 \%$ Confidence Interval for Difference } \\
\cline { 5 - 6 } & Mid SEZ & 9.26 & 0.50 & Lower Bound & Upper Bound \\
\hline \multirow{2}{*}{ Low SEZ } & High SEZ & $31.71^{*}$ & $\mathbf{0 . 0 1}$ & 9.65 & 30.38 \\
\hline \multirow{2}{*}{ Mid SEZ } & High SEZ & $22.45^{*}$ & $\mathbf{0 . 0 4}$ & 0.43 & 53.77 \\
\hline
\end{tabular}


closed mechanical ventilation that favoured fungal growth in the indoor environment. A similar finding was also observed in a study conducted in the UK across different residential settings [47].

\section{Seasonal Variation in Indoor Bioaerosol Counts}

Significant seasonal variation was observed in both indoor bacterial $(p<0.01)$ and fungal counts $(p<0.01)$ in all three socio-economic zones. A clear and significant seasonal pattern for indoor microbial flora was observed, with a declining trend from winter and spring to pre-monsoon, changing to a rising trend during monsoon and post-monsoon (Table 1 and Fig. 1).

A similar seasonal pattern in microbial counts was also reported by Premila in residential dwellings in India [48], by Caballero et al. in Mexico [49], Huang et al. in Taiwan [50] and Awadh et al. in Egypt [51]. In contrast to seasonal patterns observed in the present study, a study by Leppanen et al. [52] in Finland, Haas et al. [53] in Austria and Sitkowska et al. [54] in Poland observed a rising count of microbes in the air from winter to spring and summer. The differences between observed patterns may be due to different geographic locations and climatic variability.

The outdoor microbial counts also showed a similar seasonal trend (Fig.1); moreover, the results of mixed models incorporating all studied variables showed that the outdoor microbial counts had a significant effect $(p<0.01)$ and high estimate values $(0.85$ for fungi and 0.82 for bacteria) for indoor microbial counts (Tables 4 and 5). A possible interpretation of these results is that the indoor microbial counts replicate the seasonal variability pattern of the outdoor environment, irrespective of the different housing parameters across the SEZs. This relationship has been observed in studies across the globe, including Lee et al. [55] in the USA, Vette et al. [56] in Fransco, Talbot et al. [57] in Prague and Hussain et al. [58] in Helinski. Similar high winter and low summer outdoor microbial concentrations were reported by Aggarwal et al. [59] in Delhi, Huang et al. [50] in Taiwan and Dong et al. [60] in China.

High microbial counts were noted during the winter months. This may be due to the stability of air stratification [61] during winter, which makes dispersion and diffusion of bioaerosols difficult and raises their count in the lower atmosphere [59]. The relatively lower count observed in pre-monsoon could be due to environmental microbial stress due to high temperature $\sim 40^{\circ} \mathrm{C}$ with low humidity and high dispersion rate [59].

Exposure to high counts of bioaerosols is associated with various health issues, mainly pulmonary symptoms. Two large-scale cross-sectional surveys conducted by the central pollution control board, India, [45, 46] observed a high prevalence of respiratory morbidity during winter season in the areas of the current study.
The high exposure to bioaerosols during winter along with compromised pulmonary mechanics and decreased protection against increased air pollutants due to bronchoconstriction, airway congestion, secretions, and decrease in mucociliary clearance [59, 62] could be one of the putative factors responsible for the high prevalence of respiratory symptoms.

\section{Comparison of Indoor and Outdoor Bioaerosol Counts}

During winter and monsoon season, the difference between indoor and outdoor bacterial counts was at its maximum and was statistically significant (Table 2). The thermal inversion that occurs during winter months causes a layer of stagnant air to develop near the ground, and a lack of ventilation is maintained at most of the houses during this season in order to prevent exposure from the chilly wind blowing outside, which might have prevented free dispersion and ingression of bacteria between the indoor and outdoor environments. The low and mid SEZ houses had higher human occupancy and activities compared to the larger houses, occupied by fewer persons, in the high SEZ. This explains why the difference between indoor and outdoor counts was statistically significant in the low and mid SEZs, but not significant in the high SEZ (Table 2). The result of this work is consistent with those of Nasir et al. [47] who reported higher bioaerosol counts in the indoor environment of dwelling inhabited by more occupants compared to those by few occupants. Additionally, the washout of bioaerosols during the monsoon season decreased the counts of outdoor bioaerosols and accentuated the difference between the indoor and outdoor counts. Similar results were also reported by Manteese et al. [63] at various indoor environments in Italy and Lal et al. [64] in Delhi.

\section{Effect of Outdoor Bioaerosol Counts and Meteorological Parameters on Indoor Bioaerosol Counts}

\section{Fungi}

The indoor fungal counts were lower than the outdoor counts at all points in the seasonal cycle in all SEZs, other than during monsoon season in the mid and high SEZs. The finding in the present study is consistent with the findings of Gotes et al. [65], Jara et al. [66], and Shelton et al. [67] in the USA, and Adams et al. [68] in California, who reported lower indoor fungal counts than outer fungal counts.

The higher indoor fungal counts compared to the outdoor fungal counts during monsoon season in the mid and high SEZs might have occurred due to monsoon rain washout having reduced outdoor fungal counts so that the indoor and outdoor aerosolised fungal counts were comparable (Table 2). 
Indoor fungal counts had a statistically significant negative correlation with outdoor and indoor temperature, but correlated positively with outdoor and indoor RH (Table 3), just as in homes in Mexico by Ponce-Caballero et al. [69] and in the USA by Green et al. [70]. When further tested in the mixed model, the only parameters with a significant independent effect were outdoor fungal count $(p<0.01)$ and indoor relative humidity $(p<0.05)$ (Table 4$)$. Thus, the aerosolised fungi inside the home was primarily contributed by the outdoor environment (Tables 2 and 4); moreover, the effect of outdoor meteorological variables (outdoor temperature and relative humidity) on indoor fungal counts (Table 3) was mainly mediated through the variation that they caused in outdoor fungal counts (Table 4). Inside the home, the presence of moisture (indoor relative humidity) directly affected the growth and propagation of fungi. Similar findings were reported in a study by Jara et al. [66], Adams et al. [68], and Li et al. [71], who found indoor fungi to be mainly derived from outdoor and indoor counts to be affected by variation in outdoor fungal counts.

\section{Bacteria}

A higher indoor than outdoor count of bacteria signifies the presence of probable sources of bacteria in the indoor environment (Table 2). Similar findings were also reported by Frankel et al. [42] in the USA and Mentese et al. [63] in Turkey.

Indoor bacterial counts had a statistically significant negative correlation with outdoor and indoor temperature but correlated positively with outdoor and indoor RH (Table 3). This was consistent with results reported by Bragoszewska et al. [72] in Gliwice, Li et al. [73] in China, and Frankel et al. [42] in the USA. However, Raisi et al. [74] in Greece and Mirhoseini et al. [75] in Iran reported contradictory and insignificant results. When further tested in the mixed model, the effect of the meteorological variables was not significant, independent of SEZ, season and outdoor bacterial count, on the indoor bacterial count. The SEZ and season retained their significance in the mixed model, which indicates the potential influence of factors dependent on socio-economic status or season on indoor bacterial counts other than outdoor bacterial counts and meteorological parameters. The finding of the present study is in agreement with Frankel et al. [42], who reported the effect of seasonal dependent factors other than meteorological parameters on indoor bacterial counts.

Despite the presence of indoor sources and higher counts of indoor bacteria, the outdoor bacterial counts $(p<0.01)$ were found to significantly affect the indoor bacterial counts (Table 5). Thus, variation in outdoor bacterial counts influenced indoor bacterial counts (Fig. 1 and Table 5) and indoor bacterial counts were contributed to by bacterial aerosols generated both indoor and outdoor.

\section{Limitation}

The current study has measured total number of bacteria and fungi instead of specific pathological microbes. A specific bacterial and fungal count may vary rapidly than total microbial counts owing to differential susceptibility of different microbes to the environment. Furthermore, this study investigated only culturable bacteria and fungi.

The influence of various socio-economic factors on microbial exposure demands further study, in order to inform public policy such that it could be redesigned while taking into consideration the goal of improving living conditions and the environment in low SEZs. The findings of this study are of specific importance to developing and third-world countries, where residential areas with poor living condition are increasing in size.

\section{Conclusion}

- Microbial count in indoor residential air rises with the fall in level of hygiene and housing conditions across socio-economic zones.

- Microbial counts in the indoor air showed a similar seasonal pattern in all SEZs, despite different housing conditions; the lowest were in the premonsoon season and highest in post-monsoon and winter seasons.

- Indoor microbial count was affected by outdoor microbial counts across all SEZs, despite the use of different ventilation systems.

- Temperature and relative humidity were significantly associated with indoor microbial count, but could not fully explain the observed variations in the mixed effect model.

This study highlights the strong possibility that residents of the low socio-economic zone are exposed to higher counts of bioaerosols than residents of other areas, especially during the winter season. This may be one of the major factors responsible for the high prevalence of respiratory symptoms among inhabitants of the low SEZ in the winter season.

\section{Acknowledgements}

The authors are thankful to the Department of Science and Technology (DST) purse grant and the Ministry of Environment, Forest and Climate change (MoEF), Government of India for supporting the research work financially.

\section{Conflicts of Interest}

The authors declare no conflict of interest. 


\section{References}

1. JAENICKLE R. Abundance of cellular material and proteins in the atmosphere. Science. 308, 73, 2005.

2. HAAS D., GALLER H., LUXNER J., ZARFEL G., BUZINA W., FRIEDL H., MARTH E., HABIB J., REINTHALER F.F. The concentrations of culturable microorganisms in relation to particulate matter in urban air. Atmos. Environ. 65, 215, 2013.

3. MALECKA-ADAMOWICZ M., DONDERSKI W., OKONIEWSKA A. Evaluation of microbial air quality in a forest recreation park. Pol. J. Environ. Stud. 19 (1), 107, 2010.

4. BREZA-BORUTA B., PALUSZAK Z. Influence of water treatment plant on microbiological composition of air bioaerosol. Pol. J. Environ. Stud. 16 (5), 663, 2007.

5. PUSZ W., PLASKOWSKA E., WEBER R., KITA W. Assessing the abundance of airborne fungi in a dairy cattle barn. Pol. J. Environ. Stud. 24 (1), 241, 2015.

6. HESETLINE E., ROSEN J. WHO guidelines for indoor air quality: dampness and mould. WHO, WHO Regional Office Europe, 2009.

7. LONC E., PLEWA K. Microbiological air contamination in poultry houses. Pol. J. Environ. Stud. 19 (1), 15, 2010.

8. NASIR Z.A., COLBECK I., SULTAN S., AHMED S. Bioaerosols in residential micro- environments in low income countries: a case study from Pakistan. Environ. Pollut. 168, 15, 2012.

9. NEISI A., GOUDARZI G., AKBAR B. A., VOSOUGHI M., HASHEMZADEH H., NAIMABADI A., MOHAMMADI M.J., HASHEMZADEH B. Study of heavy metal levels in indoor dust and their health risk assessment in children of Ahvaz city, Iran. Toxin. Rev. 35, 16, 2016.

10. ADAMS R.I, BHANGAR S., PASUT W., ARENS E.A., TAYLOR J.W., LINDOW S.E., NAZAROFF W.W., BRUNS T.D. Chamber bioaerosol study: outdoor air and human occupants as sources of indoor airborne microbes. PLoS One. 10, 5, 2015.

11. NAZAROFF W.W. Indoor bioaerosol dynamics. Indoor Air. 26, 61, 2016.

12. HEO K.J., LI C.E., KIM H.B., LEE B.U. Effects of human activities on concentrations of culturable bioaerosols in indoor air environments. J. Aerosol. Sci. 104, 58, 2017.

13. KARWOWSKA E. Microbiological Air Contamination in Farming Environment. Pol. J. Environ. Stud. 14 (4), 445, 2005.

14. HOSPODSKY D., QIAN J., NAZAROFF W.W., YAMAMOTO N., BIBBY K., RISMANI-YAZDI H., PECCIA J. Human occupancy as a source of indoor airborne bacteria. PLoS One. 7, 34867, 2012.

15. PRUSSIN A.J., MARR L.C. Sources of airborne microorganisms in the built environment. Microbiome. 3, 78, 2015.

16. EMERSON J.B., KEADY P.B., CLEMENTS N., MORGAN E.E., AWERBUCH J., MILLER S.L., FIERER N. 2017. High temporal variability in airborne bacterial diversity and abundance inside single-family residences. Indoor air. 27, 576, 2017.

17. MEADOW J.F., ALTRICHTER A.E., KEMBEL S.W., KLINE J., MHUIREACH G., MORIYAMA M., NORTHCUTT D., O'CONNOR T.K., WOMACK A.M., BROWN G.Z., GREEN J.L. Indoor airborne bacterial communities are influenced by ventilation, occupancy, and outdoor air source. Indoor Air. 24, 41, 2014.
18. LUCKEY T. Introduction to intestinal microecology. Am. J. Clin. Nutr. 25, 1292, 1972.

19. QIAN J., HOSPODSKY D., YAMAMOTO N., NAZAROFF W.W., PECCIA J. Size resolved emission rates of airborne bacteria and fungi in an occupied classroom. Indoor Air. 22, 339, 2012.

20. MANDAL J., BRANDL H. Bioaerosols in indoor environment-a review with special reference to residential and occupational locations. The Open Environmental \& Biological Monitoring Journal. 4, 83, 2011.

21. HEO K.J., LIM C.E., KIM H.B., LEE B.U. Effects of human activities on concentrations of culturable bioaerosols in indoor air environments. J. Aerosol. Sci. 104, 58, 2017.

22. OCAK Y., KILICVURAN A., EREN A.B., SOFUOGLU A., SOFUOGLU S.C. Exposure to particulate matter in a mosque. Atmos. Environ. 56, 169, 2012.

23. CHEN A., CAO Q., ZHOU J., YANG B., CHANG V.W.C., NAZAROFF, W.W. Indoor and outdoor particles in an airconditioned building during and after the 2013 haze in Singapore. Build. Environ. 99, 73, 2016.

24. BALYAN P., GHOSH C., DAS S., BANERJEE B.D. Spatial variation of biogenic aerosols at different land use configurations in urban Delhi. Int. J. Appl. Environ. Sci. 12, 731, 2017.

25. BATTERMAN S.A., BURGE H. HVAC systems as emission sources affecting indoor air quality: a critical review. HVAC\&R Res. 1 (1), 61, 1995.

26. STANLEY, N.J., KUEHN T.H., KIM S.W., RAYNOR P.C., ANANTHARAMAN S., RAMAKRISHNAN M.A., GOYAL S.M. Background culturable bacteria aerosol in two large public buildings using HVAC filters as long term, passive, high-volume air samplers. J. Environ. Monitor. 10, 474, 2008.

27. HORANONT T., PHITHAKKITNUKOON S., LEONG T.W., SEKIMOTO Y., SHIBASAKI R. Weather effects on the patterns of people's everyday activities: a study using GPS traces of mobile phone users. PLoS one. 8 (21), 81153, 2013.

28. OGUNLEYE B.M. Analysis of the socio-economic characteristics and housing condition in the core neighbourhood of Akure, Nigeria. J. Geogr. Reg. Plann. 6 (6), 229, 2013.

29. GBAKEJI J.O., RILWANI K.L. Residents socio-economic characteristics and the residential mobility process in an urban space: the example of the Warri Metropolis, Delta State, Nigeria. J. Hum. Ecol. 27 (1), 45, 2009.

30. OLUWOLE O.A. PATTERN OF RESIDENTIAL MOBILITY IN KADUNA METROPOLIS, NIGERIA. Pak. Geogr. Rev. 69 (1), 46, 2014.

31. ROTHWELL J.T., MASSEY D.S. Density zoning and class segregation in US metropolitan areas. Soc. Sci. Q. 91 (5), 1123, 2010.

32. FLORIDA R., MATHESON Z., ADLER P., BRYDGES T. Thinking about the divided city. The divided city and the shape of the New Metropolis, Martin Prosperity Institute, Rotman School of Management: Toronto, Canada, 4, 2014.

33. ROTHWELL J.T., MASSEY D.S. the effect of density zoning on racial segregation in U.S. urban areas. Urban Aff. Rev. 44 (6), 779, 2009.

34. DUPONT V. Socio-spatial differentiation and residential segregation in Delhi: a question of scale. Geoforum. 35 (2), 157, 2004.

35. Seasons of Delhi - Delhi Tourism. Available online:.http:// www.delhitourism.gov.in/delhitourism/aboutus/seasons of_delhi.jsp (accessed on 2 December 2017) 
36. Department of revenue - -Delhi. Available online:. $\quad$ http://delhi.gov.in/wps/wcm/connect/ c1c16f00475bc62992bcf2825d7a2a20/circlerate4th0001. pdf?MOD=AJPERES\&lmod=-1614277266 (accessed on 2 December 2017)

37. GADHAVE S., NAGARKAR A. Kuppuswamy scale for measuring socio-economic status: Revised monthly income figures for 2015. T. Indian. J. Pediat. 82, 1175, 2015.

38. MANDAL J., CHAKRABORTY P., ROY I., CHATERJEE S., GUPTA-BHATTACHARYA S. Prevalence of allergenic pollen grains in the aerosol of the city of Calcutta, India: a two-year study. Aerobiologia. 24, 151, 2008.

39. GHOSH B., LAL H., KUSHWAHA R., HAZARIKA N., SRIVASTAVA A., JAIN V.K. Estimation of bioaerosol in indoor environment in the university library of Delhi. Sustain. Environ. Res. 23 (3), 199, 2013.

40. BHATIA L., VISHWAKARMA R. Hospital indoor airborne microflora in private and government-owned hospitals in Sagar City, India. World. J. Med. Sci. 5, 65, 2010.

41. FRANKEL M., BEKO G., TIMM M., GUSTAVSEN S., HANSEN E.W, MADSEN A.M. Seasonal variation of indoor microbial exposures and their relations to temperature, relative humidity and air exchange rates. Appl. Environ. Microb. 78, 8289, 2012.

42. MICHAŁKIEWICZ M., PRUSS A., DYMACZEWSKI Z., JEŻ-WALKOWIAK J., KWAŚNA S. Microbiological air monitoring around municipal wastewater treatment Plants. Pol. J. Environ. Stud. 20 (5), 1243, 2011.

43. YASSIN M.F., ALMOUQATEA S. Assessment of airborne bacteria and fungi in an indoor and outdoor environment. Int. J. Environ. Sci. Technol. 7 (3), 535, 2010.

44. FANG Z., GONG C., OUYANG Z., LIU P., SUN L., WANG X. Characteristic and concentration distribution of culturable airborne bacteria in residential environments in Beijing, China. Aerosol Air Qual. Res. 14 (3), 943, 2014.

45. CPCB. Epidemiological study on effect of air pollution on human health adults) in Delhi., Environmental health series; India, 309, 2008.

46. CPCB. Study on ambient air quality, respiratory symptoms and lung function of children in Delhi., Environmental health series; India, 309, 2008.

47. NASIR Z.A., COLBECK I. Assessment of bacterial and fungal aerosol in different residential settings. Water. Air. Soil. Poll. 211, 367, 2010.

48. PREMILA A. Airborne fungal diversity of residential dwellings in Imphal, Manipur, India. Int. J. Inv. Pharm. Sci. 2, 1, 2013.

49. PONCE-CABALLERO C., CERON-PALMA I.M., LOPEZ-PACHECO M., GAMBOA-MARRAFO M., QUINTAL-FRANCO C. Indoor-outdoor fungal-aerosols ratios of domestic homes in Merida, Mexico. Ingeniería. 14, 169, 2010.

50. HUANG C.Y., LEE C.C., LI F.C., MA Y.P., SU H.J.J. The seasonal distribution of bioaerosols in municipal landfill sites: a 3-yr study. Atmos. Environ. 36, 4385, 2002.

51. AWAD A.H.A., GIBBS S.G., TARWATER P.M., CASILLAS M.E., GREEN C.F. Seasonal evaluation of fine and coarse culturable bacterial aerosols from residences within a rural and an urban city in Egypt. Int. J. Environ. Health Res. 23, 269, 2013.

52. LEPPANEN H.K., NEVALAINEN A., VEPSALAINEN A., ROPONEN M., TAUBEL M., LAINE O., RANTAKOKKO P., MUTIUS E., PEKKANEN J., HYVARINEN A. Determinants, reproducibility, and seasonal variation of ergosterol levels in house dust. Indoor Air. 24, 248, 2014.

53. HAAS D., HABIB J., LUXNER J., GALLER H., ZARFEL G., SCHLACHER R., FRIEDL H., REINTHALER F.F. Comparison of background levels of culturable fungal spore concentrations in indoor and outdoor air in southeastern Austria. Atmos. Environ. 98, 640, 2014.

54. SITKOWSKA J., SITKOWSKI W., SITKOWSKI L., LUTNICKI K., ADAMEK L., WILKOLEK P. Seasonal microbiological quality of air in veterinary practices in Poland. Annu. Agr. Environ. Med. 22, 614, 2015.

55. LEE T., GRINSHPUN S.A., MARTUZEVICIUS D., ADHIKARI A., CRAWFORD C.M., LUO J., REPONEN T. Relationship between indoor and outdoor bioaerosols collected with a button inhalable aerosol sampler in urban homes. Indoor Air. 16 (1), 37, 2006.

56. VETTE A.F., REA A.W., LAWLESS P.A., RODES C.E., EVANS G., HIGHSMITH V.R., SHELDON L. Characterization of indoor-outdoor aerosol concentration relationship during the Fresno PM exposure studies. Aerosol Sci Technol. 34, 118, 2001.

57. TALBOT N., KUBELOVA L., MAKES O., ONDRACEK J., CUSACK M., SCHWARZ J., VODICKA P., ZIKOVA N., ZDIMAL V. Transformations of aerosol particles from an outdoor to indoor environment. Aerosol Air Qual. Res. 17 (3), 653, 2017.

58. HUSSEIN T., HAMERI K., AALTO P., ASMI A., KAKKO L., KULMALA M. Particle size characterization and the indoor-to-outdoor relationship of atmospheric aerosols in Helsinki. Scand. J. Work Environ. Health. 30, 54, 2004.

59. AGARWAL S. Seasonal variability in size-segregated airborne bacterial particles and their characterization at different source-sites. Environ. Sci. Pollut. Res. 24, 13519, 2017.

60. DONG L., QI J, SHAO S., ZHONG X., GAO D., CAO W., GAO J., BAI R., LONG G., CHU C. Concentration and size distribution of total airborne microbes in hazy and foggy weather. Sci. Total Environ. 541, 1011, 2016.

61. GOUDARZI G., GERAVANDI S., IDANI E., HOSSEINI S.A., BANESHI M.M., YARI A.R., VOSOUGHI M., Dobaradaran S., Shirali S., Marzooni M.B. An evaluation of hospital admission respiratory disease attributed to sulfur dioxide ambient concentration in Ahvaz from 2011 through 2013. Environ. Sci. Pollut. Res. 23, 22001, 2016.

62. GIESBRECHT G.G. The respiratory system in a cold environment. Aviat. Space Environ. Med. 66, 890, 1995.

63. MENTESE S., RAD A.Y., ARISOY M., GULLU G. Seasonal and spatial variations of bioaerosols in indoor urban environments, Ankara, Turkey. Indoor Built Environ. 21, 797, 2012.

64. LAL H., PUNIA T., GHOSH B., SRIVASTAVA A., JAIN V.K. Comparative study of bioaerosol during monsoon and post-monsoon seasons at four sensitive sites in Delhi region. International Journal of Advancement in Earth and Environmental Sciences. 1 (2), 1, 2013.

65. GOTS R.E., LAYTON N.J., PIRAGES S.W. Indoor health: background levels of fungi. Am. Ind. Hyg. Assoc. J. 64, 427, 2003.

66. JARA D., PORTNOY J., DHAR M., BARNES C. Relation of indoor and outdoor airborne fungal spore levels in the Kansas City metropolitan area. Int. Aller. Asthm. Proc. 38, 130, 2017.

67. SHELTON B.G., KIRKLAND K.H., FLANDERS W.D., MORRIS G.K. Profiles of airborne fungi in buildings 
and outdoor environments in the United States. Appl. Environ. Microb. 68 (4), 1743, 2002.

68. ADAMS R.I., MILETTO M., TAYLOR J.W., BRUNS T.D. Dispersal in microbes: fungi in indoor air are dominated by outdoor air and show dispersal limitation at short distances. ISME J. 7 (7), 1262, 2013.

69. PONCE-CABALLERO C., GAMBOA-MARRUFO M., LÓPEZ-PACHECO M., CERÓN-PALMA I., QUINTALFRANCO C., GIÁCOMAN-VALLEJOS G., LORÍAARCILA J.H. Seasonal variation of airborne fungal propagules indoor and outdoor of domestic environments in Mérida, Mexico. Atmósfera. 26 (3), 369, 2013.

70. GREEN C.F., SCARPINO P.V., GIBBS S.G. Assessment and modeling of indoor fungal and bacterial bioaerosol concentrations. Aerobiologia. 19 (3),159, 2003.

71. LI D.W., KENDRICK B. A year-round comparison of fungal spores in indoor and outdoor air. Mycologia. 1, 190, 1995.
72. BRĄGOSZEWSKA E., MAINKA A., PASTUSZKA J. Concentration and size distribution of culturable bacteria in ambient air during spring and winter in Gliwice: A typical urban area. Atmosphere, 8 (12), 239, 2017.

73. LI Y., FU H., WANG W., LIU J., MENG Q., WANG W. Characteristics of bacterial and fungal aerosols during the autumn haze days in Xi'an, China. Atmos. Environ. 122, 439, 2015.

74. RAISI L., LAZARIDIS M., KATSIVELA E. Relationship between airborne microbial and particulate matter concentrations in the ambient air at a Mediterranean site. Global NEST J. 12 (1), 84, 2010.

75. MIRHOSEINI S.H., NIKAEEN M., SATOH K., MAKIMURA K. Assessment of airborne particles in indoor environments: Applicability of particle counting for prediction of bioaerosol concentrations. Aerosol Air Qual. Res. 16 (8), 1903, 2016. 